DOI: 10.22630/EIOGZ.2014.108.47

Zeszyty Naukowe Szkoły Głównej Gospodarstwa Wiejskiego

Ekonomika i Organizacja Gospodarki Żywnościowej nr 108, 2014: 159-176

\title{
Zmiany na rynku jabłek w krajach Unii Europejskiej w latach 2000-2010
}

\section{Wstęp}

Jabłoń jest drzewem klimatu umiarkowanego i w tej strefie koncentruje się jej uprawa. Jednak w ostatnich latach z powodzeniem podjęto działania, aby uprawy jabłoni przesunąc do strefy podzwrotnikowej [Sadownictwo... 1995, s. 181]. Znacznie większa liczba gatunków roślin sadowniczych uprawiana jest w strefie klimatu subtropikalnego i tropikalnego [Kawecka i Kryńska (red.) 1992, s. 5-12]. Na szerokie rozpowszechnienie upraw jabłoni wpłynęła duża wartość gospodarcza drzew. W wyniku wiekowej selekcji, krzyżowań i zabiegów hodowlanych uprawianych np. w połowie lat 90 . XX wieku było na świecie ponad 10 tys. odmian. Owoc jako ostateczny produkt jest przedmiotem zainteresowania nie tylko konsumenta, ale także przechowalnictwa, obrotu i przetwórstwa. Jabłoń (Malus) należy do rzędu różowców (Rosales), rodziny różowatych (Rosaceae), podrodziny ziarnkowatych (szupinkowych). Występuje około 30 gatunków jabłoni, głównie w klimacie umiarkowanym w Europie i Azji, a także około 9 gatunków rośnie dziko w Ameryce [Rejman (red.) 1994, s. 19]. Ponad 20 gatunków jabłoni pochodzi z trzech regionów kontynentu azjatyckiego, to jest Kaukazu, Azji Środkowej i Chin. Kilka gatunków pochodzi z kontynentu północnoamerykańskiego, ale nie odegrały one znaczącej roli w rozwoju jabłoni uprawnej [Sadownictwo... 1995, s. 181]. Liczba gatunków roślin sadowniczych uprawianych w różnych regionach świata wynosi kilkaset, a być może zbliża się do tysiąca. Większość światowej produkcji owoców daje jednak niewiele, zaledwie 20-30 gatunków.

$\mathrm{Na}$ rozwój nowoczesnego sadownictwa w Europie miały istotny wpływ gospodarstwa sadownicze w Stanach Zjednoczonych - specjalizowały się one w produkcji towarowej owoców dostarczanych na rynek. Najważniejsze odmiany 
towarowe (tj.: Red Delicious, Golden Delicious, Jonatan i McIntosh), a wiele odmian na rynku to ich potomkowie (Lobo, Cortland, Jonagold, Gloster), sa popularne nadal wśród konsumentów [Pieniążek 2000, s.15]. Dynamiczne zmiany i rozwój w sadownictwie europejskim nastąpił w latach 60. i 70., zwłaszcza we Włoszech, Niemczech, Francji, w Polsce natomiast w latach 70. i 80., choć szczególnie pozytywne zmiany można dostrzec od początku lat 90 . XX wieku [Pieniążek 2000, s. 21], oraz na początku XXI wieku - po wejściu Polski do UE. Stale wprowadzany postęp (narzędzia, tj. opryskiwacze, sekatory, kosiarki, rozdrabniacze gałęzi, zbieracze do owoców, palety, podnośniki widłowe, chłodnie, linie sortownicze i inne) i nowoczesne odmiany jabłoni przyniosły wymierny efekty. Dzięki postępowi jaki dokonał się w sadownictwie przez ostatnie czterdzieści lat, a zwłaszcza po zmianie niskopiennych sadów jabłoniowych na karłowe, Polska zalicza się do największych producentów jabłek w Europie i na świecie.

\section{Cel pracy, materiał źródłowy i metody badawcze}

Celem artykułu jest przedstawienie zmian zachodzących w powierzchni uprawy jabłoni, produkcji jabłek, skali i kierunkach ich handlu zagranicznego oraz konsumpcji jabłek w krajach Unii Europejskiej w latach 2000-2010. W opracowaniu wykorzystano wtórne źródła informacji pochodzące $\mathrm{z}$ baz danych Faostat 2012, GUS, opracowania Komisji Europejskiej i inne. Praca została zrealizowana w ramach projektu badawczego grantu NCN Nr 3745/B/H03/2011/40. W analizie problemu badawczego wykorzystano metody porównawczą oraz opisową.

\section{Produkcja jabłek w krajach Unii Europejskiej}

Produkcja owoców i warzyw w UE stanowi 8-10\% światowej produkcji, kształtującej się w granicach 1,2 mln t. Najważniejszymi owocami produkowanymi przez kraje Wspólnoty są: jabłka - ponad 9-12 mln t, pomarańcze $6,8 \mathrm{mln}$ t, gruszki - ok. 3 mln t. Do głównych producentów jabłek w UE należą Polska, Francja i Włochy, których udział wynosi $60 \%$, a z uwzględnieniem Niemiec i Hiszpani to $75 \%$ całkowitej unijnej produkcji. Na terytorium UE uprawianych jest około 25 odmian jabłoni, w tym do najpopularniejszych należą: Golden Delicious, Jonagold, Gala. Poza tym w Niemczech i Holandii także Elstar, a w Polsce i na Węgrzech Idared i Jonathan. Do końca lat 80. XX wieku na terenie Europy powierzchnia upraw jabłoni była największa na świecie. Wyspecjalizowana produkcja jabłek odbywała się głównie w 8 krajach obecnych członków UE, tj. we Francji, Włoszech (najnowocześniejsze sady w latach 
60. i 70.), w Wielkiej Brytanii, Grecji, Bułgarii, Hiszpanii, Portugalii, Rumunii. Jabłonie popularne $\mathrm{w}$ uprawie były $\mathrm{w}$ tym samym czasie także $\mathrm{w}$ republikach na obszarze byłego ZSRR (Ukrainie, Białorusi, Uzbekistanie), a poza Europa sadownictwo rozwijało się dynamicznie zwłaszcza w USA, Kanadzie, Japonii, Turcji, Indiach, Australii, Iranie, Chile i Libanie. Udział Europy w światowej strukturze powierzchni upraw jabłoni w kolejnych dwóch dekadach spadł z 65\% do $51 \%$ w latach 80 ., a obecnie stanowi tylko $26,8 \%$. Zmniejszenie rangi Europy w uprawie jabłoni podyktowane było kilkoma czynnikami: wprowadzaniem na innych kontynentach nowych odmian o zgoła odmiennych niż dotychczas warunkach uprawy (bardziej odpornych np. na: suszę, mrozy, wilgoć itp.), cechujących się korzystnymi parametrami handlowymi oraz wysokim uzyskiem owoców z hektara sadu, co stworzyło sprzyjające warunki do ekspansywniejszego wkraczania na arenę międzynarodową państw, gdzie dotychczas nie było tradycji sadowniczych w kierunku uprawy jabłoni - Chin, Turcji, Indii czy Iranu. Wprowadzenie do gospodarki sadowniczej nowoczesnych maszyn i urządzeń oraz technologii uprawy, które pozwalały przy zmieniających się preferencjach i wymaganiach klientów zaoferować produkt wykorzystywany zarówno jako jabłko deserowe w bezpośredniej konsumpcji, jak i surowiec do dalszego przetworzenia przez zakłady przetwórstwa. W cztery dekady - do połowy lat 90 . XX wieku areał uprawy jabłoni na świecie wzrósł ponad 2,5-krotnie (do 6,3 mln ha), przy stopniowej redukcji o około $1 / 5$ do $4,76 \mathrm{mln}$ ha w 2004 roku i względnej stabilizacji w granicach 4,7-4,9 $\mathrm{mln}$ ha do 2010 roku. Konkurencją dla jabłek są banany, pomarańcze oraz winogrona, choć coraz częściej na stoły w Europie trafiają atrakcyjne nie tylko smakowo, ale też cenowo brzoskwinie, mandarynki, grejpfrut, czy do niedawna mniej popularne owoce, takie jak: daktyle, pistacje, granaty, kiwi, opuncja, awokado, figi i inne ${ }^{1}$ [Poniedziałek 2001, s. 5-25].

W latach 2000-2010 w krajach UE można było zaobserwować z jednej strony zmniejszenie się znaczenia uprawy jabłoni w sadach, jak we Francji (z ok. 10 do $7 \%$ ), Niemczech (z 17 do 5,8\% - z areału 125 ha do zaledwie 32 tys. ha) czy Hiszpanii (z 48,8 ha do ok. 30 tys. ha) - tabela 1. Z drugiej natomiast wyraźny wzrost we Włoszech, na Węgrzech (o 3 p.p. - do 7,8\%), czy Polsce (z 22 do 34\% w 2010 r.). Łącznie produkcja jabłek prowadzona była na coraz mniejszej powierzchni - 550 tys. ha (spadek o 1/4). Rozmieszczenie produkcji jabłek nie jest równomiernie w krajach UE-27. Wraz ze zamianą niskopiennych sadów jabłoniowych na karłowe intensyfikacja oraz wielkość produkcji jabłek z hektara zdecydowanie wzrosła. W skali świata od początku lat 60 . produkcja jabłek wzrosła o 180\% - 62,6 mln t. W Unii Europejskiej w zależności od sezonu

\footnotetext{
${ }^{1}$ Persymona, kasztan jadalny, pigwa, ceratonia, nieśplik czy lima, cytron, nagami, marumi, kumkwat, limekwat, bergamoty, papaja i inne.
} 
162

Tabela 1

Powierzchnia upraw jabłoni w krajach UE-27 w latach 2000-2010 [tys. ha]

\begin{tabular}{|c|c|c|c|c|c|c|c|c|c|c|c|}
\hline \multirow{2}{*}{ Kraj } & \multicolumn{11}{|c|}{ Lata } \\
\hline & 2000 & 2001 & 2002 & 2003 & 2004 & 2005 & 2006 & 2007 & 2008 & 2009 & 2010 \\
\hline Polska & 165,1 & 166,4 & 168,5 & 159,3 & 175,2 & 169,7 & 162,0 & 175,6 & 172,0 & 173,6 & 188,2 \\
\hline Włochy & 62,5 & 62,7 & 60,5 & 56,9 & 57,6 & 57,1 & 57,1 & 56,0 & 59,0 & 58,4 & 57,9 \\
\hline Rumunia & 71,0 & 73,0 & 72,4 & 71,6 & 73,4 & 81,7 & 59,3 & 59,0 & 54,7 & 52,6 & 56,4 \\
\hline Francja & 69,7 & 60,2 & 65,6 & 59,8 & 58,1 & 57,7 & 55,2 & 53,8 & 42,1 & 41,2 & 40,0 \\
\hline Węgry & 34,5 & 57,2 & 35,8 & 43,5 & 43,2 & 42,0 & 39,1 & 40,5 & 43,1 & 36,6 & 34,0 \\
\hline Niemcy & 125 & 70,0 & 69,2 & 31,2 & 32,3 & 32,3 & 32,5 & 31,7 & 31,8 & 31,8 & 31,8 \\
\hline Hiszpania & 48,8 & 42,3 & 43,2 & 46,0 & 42,2 & 39,0 & 37,8 & 36,9 & 33,4 & 30,0 & 31,7 \\
\hline W. Brytania & 13,0 & 11,2 & 9,9 & 9,1 & 9,2 & 8,5 & 15,6 & 15,0 & 15,5 & 15,6 & 15,7 \\
\hline Grecja & 14,1 & 15,5 & 13,7 & 13,6 & 13,4 & 13,4 & 13,3 & 13,2 & 12,0 & 12,1 & 13,5 \\
\hline Portugalia & 21,2 & 21,3 & 21,4 & 21,6 & 21,4 & 21,3 & 20,7 & 20,5 & 20,6 & 20,6 & 13,2 \\
\hline Litwa & 31,0 & 31,3 & 27,9 & 19,3 & 19,3 & 20,8 & 14,9 & 13,3 & 11,7 & 11,6 & 12,1 \\
\hline Czechy & 12,0 & 10,0 & 12,0 & 12,1 & 12,7 & 12,4 & 9,0 & 8,6 & 8,8 & 10,0 & 9,2 \\
\hline Holandia & 12,8 & 11,7 & 11,2 & 10,3 & 10,2 & 9,7 & 9,6 & 9,4 & 9,3 & 9,1 & 8,7 \\
\hline Belgia & 8,9 & 8,8 & 8,6 & 8,4 & 8,3 & 7,9 & 7,4 & 7,2 & 7,2 & 7,1 & 6,9 \\
\hline Austria & 5,9 & 6,0 & 5,8 & 5,8 & 6,0 & 6,0 & 6,0 & 6,0 & 6,0 & 6,0 & 6,0 \\
\hline Bułgaria & 13,0 & 9,9 & 6,0 & 7,8 & 7,4 & 5,4 & 5,7 & 5,4 & 5,4 & 5,2 & 5,2 \\
\hline Estonia & 7,2 & 10,5 & 9,9 & 8,6 & 8,9 & 6,5 & 5,1 & 4,3 & 4,0 & 4,2 & 3,3 \\
\hline Łotwa & 8,1 & 8,2 & 8,2 & 8,2 & 8,3 & 8,5 & 9,4 & 7,4 & 5,1 & 4,1 & 3,3 \\
\hline Słowacja & 3,1 & 4,1 & 4,7 & 3,5 & 3,3 & 3,2 & 3,3 & 3,2 & 3,4 & 3,6 & 3,2 \\
\hline Słowenia & 3,1 & 3,1 & 3,3 & 3,1 & 3,1 & 3,1 & 3,1 & 2,9 & 2,9 & 2,7 & 2,8 \\
\hline Irlandia & 0,8 & 0,7 & 0,6 & 0,5 & 1 & 1,8 & 2,1 & 2,1 & 1,9 & 1,9 & 1,8 \\
\hline Szwecja & 1,4 & 1,4 & 1,3 & 1,3 & 1,4 & 1,4 & 1,6 & 1,4 & 1,4 & 1,5 & 1,5 \\
\hline Dania & 1,7 & 1,8 & 1,6 & 1,6 & 1,6 & 1,6 & 1,5 & 1,5 & 1,5 & 1,5 & 1,4 \\
\hline Cypr & 1,1 & 1,1 & 1,1 & 1,2 & 1,2 & 1,3 & 1,3 & 1,1 & 0,9 & 1,2 & 0,9 \\
\hline Luksemburg & 1,1 & 1,1 & 1,1 & 1,0 & 1,0 & 1,0 & 1,0 & 1,0 & 1,0 & 1,0 & 0,9 \\
\hline Finlandia & 0,5 & 0,5 & 0,6 & 0,6 & 0,6 & 0,6 & 0,6 & 0,6 & 0,7 & 0,7 & 0,7 \\
\hline Malta & 0 & 0 & 0 & 0 & 0 & 0 & 0 & 0 & 0 & 0 & 0 \\
\hline UE-27 & 736,6 & 690 & 664,1 & 605,9 & 620,3 & 613,9 & 574,1 & 577,6 & 555,4 & 543,9 & 550,3 \\
\hline
\end{tabular}

Źródło: Faostat 2012.

uzyskiwano w latach 2000-2010 około 11-14 mln ton jabłek rocznie, co stanowiło blisko dwadzieścia kilka procent w ich światowej produkcji, podczas gdy trzy dekady wstecz 41\%. Do głównych producentów jabłek we Wspólnocie zalicza się Włochy, Polskę, Francję, Niemcy i Hiszpanię (tab. 2).

Ugruntowywanie pozycji Chin z 2 do 39\% światowej produkcji jabłek, zmniejszenie znaczenia sadowników z USA z 12 do $7 \%$ oraz przemiany na 
Tabela 2

Produkcja jabłek w UE-27 w latach 2000-2010 [tys. ton]

\begin{tabular}{|l|c|c|c|c|c|c|c|c|c|c|c|}
\hline \multirow{2}{*}{ Kraj } & \multicolumn{9}{|c|}{ Lata } \\
\cline { 2 - 15 } & 2000 & 2001 & 2002 & 2003 & 2004 & 2005 & 2006 & 2007 & 2008 & 2009 & 2010 \\
\hline Włochy & 2232 & 2299 & 2199 & 1954 & 2136 & 2192 & 2131 & 2230 & 2210 & 2326 & 2205 \\
\hline Polska & 1450 & 2434 & 2168 & 2428 & 2522 & 2075 & 2305 & 1040 & 2831 & 2626 & 1859 \\
\hline Francja & 2157 & 2397 & 2432 & 2137 & 2204 & 2242 & 2081 & 2144 & 1702 & 1730 & 1711 \\
\hline Niemcy & 3137 & 1779 & 1471 & 818 & 980 & 891 & 948 & 1070 & 1047 & 1071 & 835 \\
\hline Hiszpania & 814 & 917 & 695 & 881 & 691 & 774 & 650 & 721 & 662 & 595 & 596 \\
\hline Rumunia & 490 & 507 & 492 & 811 & 1098 & 638 & 590 & 475 & 459 & 518 & 553 \\
\hline Węgry & 695 & 605 & 527 & 508 & 700 & 510 & 537 & 171 & 569 & 575 & 497 \\
\hline Holandia & 461 & 408 & 354 & 359 & 436 & 359 & 365 & 391 & 375 & 407 & 338 \\
\hline Austria & 490 & 410 & 479 & 423 & 484 & 453 & 509 & 478 & 551 & 486 & 332 \\
\hline Belgia & 546 & 337 & 349 & 319 & 356 & 325 & 358 & 358 & 335 & 311 & 269 \\
\hline Grecja & 315 & 248 & 281 & 208 & 275 & 250 & 289 & 252 & 235 & 260 & 239 \\
\hline W. Brytania & 209 & 212 & 179 & 144 & 170 & 218 & 269 & 243 & 243 & 229 & 228 \\
\hline Portugalia & 227 & 265 & 301 & 287 & 277 & 249 & 258 & 247 & 239 & 280 & 165 \\
\hline Słowenia & 130 & 78 & 142 & 102 & 140 & 106 & 119 & 115 & 103 & 96 & 118 \\
\hline Czechy & 339 & 221 & 317 & 243 & 281 & 209 & 159 & 113 & 158 & 170 & 100 \\
\hline Malta & 66 & 55 & 33 & 12 & 32 & 66 & 102 & 63 & 57 & 57 & 51 \\
\hline Słowacja & 82 & 50 & 51 & 61 & 42 & 47 & 31 & 18 & 42 & 50 & 45 \\
\hline Bułgaria & 89 & 43 & 26 & 38 & 39 & 26 & 26 & 26 & 24 & 36 & 43 \\
\hline Irlandia & 15 & 17 & 16 & 15 & 25 & 45 & 42 & 45 & 47 & 43 & 40 \\
\hline Litwa & 99 & 151 & 80 & 98 & 34 & 97 & 100 & 41 & 74 & 53 & 34 \\
\hline Dania & 25 & 20 & 19 & 32 & 35 & 35 & 32 & 32 & 34 & 30 & 28 \\
\hline Szwecja & 22 & 20 & 18 & 22 & 19 & 18 & 24 & 21 & 22 & 21 & 24 \\
\hline Luksemburg & 12 & 4 & 11 & 4 & 11 & 4 & 9 & 4 & 10 & 10 & 11 \\
\hline Łotwa & 35 & 36 & 50 & 36 & 7 & 38 & 34 & 31 & 29 & 13 & 10 \\
\hline Cypr & 11 & 9 & 11 & 10 & 11 & 11 & 11 & 9 & 7 & 7 & 7 \\
\hline Finlandia & 3 & 4 & 3 & 3 & 3 & 4 & 3 & 4 & 4 & 4 & 4 \\
\hline Estonia & 19 & 15 & 17 & 5 & 2 & 11 & 3 & 4 & 2 & 5 & 2 \\
\hline UE-27 & 14167 & 13542 & 12720 & 11955 & 13008 & 11892 & 11985 & 10344 & 12069 & 12007 & 10344 \\
\hline Zrodio:Faos & 2012 & & & & & & & & & \\
\hline
\end{tabular}

Źródło: Faostat 2012.

rynku wspólnotowym sprawiają, że wzrasta konkurencja na rynku tego owocu w skali globu i coraz trudniej jest go sprzedać przy coraz niższej cenie, mimo coraz wyższych parametrów jakościowych produktu deserowego i przemysłowego. Właściciele sadów poszukują z jednej strony optymalnych metod zarządzania mających na celu redukcję kosztów i podnoszących efektywność gospodarstwa sadowniczego [Hester i Cacho 2003, s.137-154], a z drugiej poszukują metod 
przyjaznych dla środowiska i akceptowanych przez konsumentów [Pizło 2014, s. 185-193].

Polska na tle pozostałych państw, nie tylko UE, ale i świata jest czołowym producentem jabłek. Produkcja ogółem powyżej 2,5 mln ton stawia Polskę na pierwszym miejscu wśród krajów UE-27, a w przypadku jabłek deserowych w granicach około 1,3 mln ton, tuż po Włoszech. Łączna produkcja jabłek deserowych i przemysłowych w granicach $2,8 \mathrm{mln}$ ton rocznie powoduje, że dostarczamy na rynek około 3,5\% światowego surowca, stanowi to w krajach UE 20-25\% produkcji. Przyczyn tego stanu należy upatrywać w dominacji wśród nasadzeń drzew karłowych (około 2,5 tys./ha) na słabo rosnących podkładkach (od 1000 do 1200 na hektarze) w gospodarstwach sadowniczych [Makosz 2012a, c].

Zmiany dynamiki produkcji jabłek w latach 2000-2010, nie tylko w krajach UE podyktowane były kilkoma czynnikami - zarówno o charakterze ekonomicznym, jak i pozaekonomicznym. Należą do nich między innymi: warunki naturalne, przyrodnicze (pogodowe) - mają one charakter losowy (niecykliczny), niejednokrotnie trudny do przewidzenia (tj. fala przymrozków w okresie zawiązywania zalążków, ulewne opady deszczu, gradobicia czy długotrwała susza) i wpływają na poziom zbiorów i plonów, co ma swoje konsekwentne odzwierciedlenie w poziomie cen. Większość świeżych jabłek o wysokiej jakości trafia tuż po zbiorze do konsumpcji. W zależności od kraju skala produkcji sadowniczej UE nie zawsze pozwala na zaspokojenie potrzeb rynku wewnętrznego. Nie tylko w przypadku Polski nadwyżki surowca przeznaczane są na eksport. Część owoców trafia do konsumenta $\mathrm{w}$ formie mrożonej lub przetworzonej. Te gorszej jakości lub przemysłowe znajdują zastosowanie w przetwórstwie (do wyrobu np. koncentratu soku jabłkowego, przecierów, dżemów, musów, a także napojów alkoholowych) czy jako suszone, rozdrobnione, wykorzystywane są w piekarnictwie i cukiernictwie. Na ich atrakcyjność na rynku dla przemysłu rolno-spożywczego i większe zagospodarowanie $\mathrm{w}$ tworzeniu wartości dodanej ma wpływ przede wszystkim kształtowanie się $\mathrm{w}$ danym roku ceny surowca oraz relacje podażowo-popytowe.

W sadach tracą na znaczeniu odmiany starsze, np. Cortland, McIntosh, zyskują zaś stosunkowo niedawno wprowadzone - Gala, Fuji, Jonathan, Pinova (tab. 3 i 4). Tego rodzaju zmiany struktury odmianowej drzew jabłoni w sadach są podyktowane między innymi zmieniającymi się preferencjami konsumentów i oczekiwaniami odbiorców (np. sieci handlowych). Pomiędzy poszczególnymi krajami we Wspólnocie występują różnice w poziomie i strukturze zbioru odmian jabłek. Dla przykładu Polacy zazwyczaj w celach konsumpcyjnych nabywają jabłka duże, dobrze wybarwione, częściej czerwone odmiany niż zielone, niekoniecznie słodkie, podczas gdy w Niemczech czy Holandii konsumenci wolą jabłka Elstar, Jonagold. W UE w latach 2005-2011 największą produkcję jabłek notowano w przypadku dwóch najpopularniejszych wśród konsumentów odmian: 
Tabela 3

Plony jabłek w krajach UE-27 w latach 2000-2009 [dt/ha]

\begin{tabular}{|c|c|c|c|c|c|c|c|c|c|c|}
\hline \multirow{2}{*}{ Kraj } & \multicolumn{10}{|c|}{ Lata } \\
\hline & 2000 & 2001 & 2002 & 2003 & 2004 & 2005 & 2006 & 2007 & 2008 & 2009 \\
\hline Austria & 819,7 & 676,4 & 817,2 & 720,5 & 797,8 & 746,9 & 840,2 & 788,5 & 914,5 & 802,5 \\
\hline Holandia & 359,1 & 348,2 & 316,7 & 348,7 & 426,7 & 368,7 & 381,7 & 416,0 & 403,2 & 447,3 \\
\hline Belgia & 612,9 & 382,5 & 405,3 & 379,9 & 428,7 & 409,6 & 481,5 & 496,2 & 463,4 & 439,5 \\
\hline Włochy & 357,0 & 367,0 & 363,3 & 343,2 & 371,2 & 383,6 & 372,9 & 398,1 & 374,6 & 398,9 \\
\hline Francja & 309,5 & 398,2 & 370,8 & 357,2 & 379,3 & 388,2 & 377,2 & 398,6 & 371,7 & 378,8 \\
\hline Słowenia & 420,8 & 254,6 & 430,3 & 328,0 & 451,5 & 342,7 & 384,6 & 398,4 & 358,0 & 351,4 \\
\hline Niemcy & 250,9 & 254,1 & 212,6 & 262,5 & 302,9 & 275,6 & 291,5 & 337,3 & 329,2 & 336,6 \\
\hline Iralndia & 182,5 & 244,3 & 263,3 & 302,4 & 250,0 & 250,0 & 210,0 & 214,3 & 244,3 & 228,7 \\
\hline Dania & 148,9 & 112,2 & 119,4 & 197,7 & 220,7 & 218,3 & 206,9 & 215,3 & 223,5 & 209,2 \\
\hline Hiszpania & 166,9 & 216,8 & 160,8 & 191,5 & 163,8 & 198,6 & 171,9 & 195,4 & 198,3 & 198,3 \\
\hline Grecja & 223,1 & 159,8 & 205,1 & 152,9 & 205,3 & 187,2 & 217,2 & 190,5 & 195,6 & 193,4 \\
\hline Czechy & 282,9 & 221,6 & 263,2 & 201,0 & 221,1 & 168,7 & 176,2 & 131,3 & 180,2 & 170,4 \\
\hline Węgry & 201,3 & 105,8 & 147,1 & 116,7 & 162,0 & 121,4 & 137,3 & 42,2 & 131,9 & 157,0 \\
\hline W. Brytania & 160,6 & 189,3 & 182,1 & 157,4 & 185,8 & 258,1 & 173,0 & 176,1 & 156,7 & 151,9 \\
\hline Polska & 87,9 & 146,3 & 128,7 & 152,4 & 143,9 & 122,3 & 142,3 & 59,2 & 164,6 & 151,3 \\
\hline Szwecja & 154,0 & 140,3 & 135,0 & 161,3 & 134,1 & 122,8 & 150,0 & 150,0 & 158,6 & 146,7 \\
\hline Portugalia & 106,9 & 124,0 & 140,5 & 132,8 & 129,5 & 117,0 & 125,0 & 120,7 & 115,9 & 135,8 \\
\hline Luksemburg & 112,8 & 42,0 & 105,5 & 38,2 & 104,9 & 37,4 & 89,0 & 40,4 & 102,9 & 102,9 \\
\hline Rumunia & 69,0 & 69,5 & 67,9 & 113,3 & 149,6 & 78,1 & 99,6 & 80,5 & 83,9 & 98,3 \\
\hline Bułgaria & 68,7 & 43,3 & 44,2 & 49,4 & 53,6 & 48,5 & 46,1 & 48,1 & 43,5 & 68,3 \\
\hline Finlandia & 54,3 & 69,7 & 56,3 & 47,6 & 43,1 & 55,9 & 51,4 & 53,4 & 64,1 & 65,4 \\
\hline Słowacja & 266,9 & 121,7 & 109,6 & 173,3 & 128,0 & 147,0 & 92,0 & 54,6 & 122,0 & 64,4 \\
\hline Cypr & 100,0 & 82,3 & 95,6 & 81,5 & 85,8 & 84,6 & 84,1 & 80,9 & 69,4 & 54,7 \\
\hline Litwa & 31,8 & 48,3 & 28,7 & 50,6 & 17,6 & 46,4 & 67,0 & 30,5 & 63,7 & 46,1 \\
\hline Malta & 66,0 & 55,0 & 41,3 & 40,0 & 40,0 & 41,3 & 72,9 & 42,0 & 38,0 & 38,0 \\
\hline Łotwa & 43,6 & 44,2 & 61,3 & 43,8 & 8,3 & 44,1 & 35,9 & 41,4 & 56,2 & 31,0 \\
\hline Estonia & 25,9 & 14,3 & 17,3 & 5,7 & 2,4 & 16,3 & 5,5 & 9,4 & 5,6 & 12,9 \\
\hline
\end{tabular}

Źródło: Obliczenia własne na podstawie Faostat 2012.

Golden Delicious - ponad 2,5 mln ton i o ponad połowę mniej Gali. Na zbliżonym poziomie od 550-750 tys. ton kształtowała się produkcja innych równie poszukiwanych odmian, takich jak: Red Delicious, Jonagold i Idared, choć niewiele ustępuje im miejsca Elstar (tab. 4), przy zdecydowanym spadku zbiorów jabłek Cortland. W Polsce przy zbiorach około 2,7 mln ton jabłek, aby zagospodarować je po opłacalnych cenach trzeba wyeksportować około 700 tys. ton, w kraju spożyć 
Tabela 4

Zbiory jabłek wybranych odmian w UE-27 w latach 2005-2011 [tys. ton]

\begin{tabular}{|l|c|c|c|c|c|c|c|}
\hline \multirow{2}{*}{ Odmiana jabłek } & \multicolumn{7}{|c|}{ Lata } \\
\cline { 2 - 8 } & 2005 & 2006 & 2007 & 2008 & 2009 & 2010 & 2011 \\
\hline Brabeurn & 296 & 279 & 318 & 295 & 338 & 289 & 311 \\
\hline Cortland & 100 & 155 & 75 & 136 & 80 & 50 & 70 \\
\hline Elstar & 427 & 431 & 487 & 468 & 487 & 361 & 429 \\
\hline Fuji & 130 & 133 & 188 & 205 & 245 & 250 & 254 \\
\hline Gala & 1052 & 1016 & 1024 & 1045 & 1074 & 986 & 1059 \\
\hline Gloster & 100 & 128 & 93 & 164 & 113 & 111 & 116 \\
\hline Golden Delicious & 2561 & 2340 & 2450 & 2506 & 2630 & 2401 & 2533 \\
\hline Granny Smith & 315 & 308 & 305 & 311 & 341 & 339 & 338 \\
\hline Idared & 693 & 624 & 292 & 804 & 795 & 569 & 575 \\
\hline Jonagold & 650 & 633 & 651 & 801 & 737 & 522 & 594 \\
\hline Jonagored & 190 & 210 & 234 & 203 & 204 & 178 & 182 \\
\hline Jonathan & 31 & 35 & 51 & 257 & 305 & 282 & 221 \\
\hline Lobo & 150 & 210 & 100 & 203 & 100 & 61 & 100 \\
\hline Pinova & 15 & 17 & 20 & 30 & 35 & 27 & 30 \\
\hline Red Delicious & 660 & 631 & 600 & 743 & 724 & 662 & 635 \\
\hline Red Jonaprince & & & & 21 & 29 & 28 & 31 \\
\hline Szampion & 277 & 307 & 172 & 395 & 323 & 257 & 293 \\
\hline
\end{tabular}

Źródło: Eurostat 2012.

co najmniej 600 tys. ton, a na sok zagęszczony przerobić pozostałe $1,4 \mathrm{mln}$ ton [Makosz 2012d]. Można uznać, że odmiany, które dominują w polskich sadach, uzupełniają ofertę towarową w UE, tu dominującą odmianą był Golden Delicious, stanowiąc w latach 2005-2011 nawet 1/3 wszystkich upraw, w drugiej kolejności odmiana Gala i na trzecim miejscu grupa odmian Jonagold [Pizło 2012].

Plony jabłek uzyskiwany z hektara sadu wzrastają nie tylko na poziomie globalnym, ale także w poszczególnych krajach prowadzących gospodarkę sadowniczą, co można zaobserwować na przykładzie UE. Produkcja jabłek w większości krajów wspólnoty przekracza poziom $140 \mathrm{dt} / \mathrm{ha}$, a rekordzistami są sadownicy z Austrii, uzyskując ponad $800 \mathrm{dt} / \mathrm{ha}$, Holandii - $447 \mathrm{dt} / \mathrm{ha}$, Belgii - $450 \mathrm{dt} / \mathrm{ha}$ oraz Włoch, Francji, Słowenii czy Niemiec - ponad 380 dt/ha (tab. 3). Polska do 2000 roku z plonem $87,9 \mathrm{dt} /$ ha, ze średnioroczną produkcją jabłek około 1,5 mln ton i eksportem jabłek deserowych na poziomie około 200-250 tys. ton nie stanowiła zagrożenia dla sadowników z UE. Jednak w ostatniej dekadzie, zwłaszcza po przystąpieniu do Wspólnoty, unowocześniono gospodarkę sadowniczą, wprowadzono w nasadzeniach plenniejsze i smaczniejsze odmiany - preferowane przez 
rolników dotychczas McIntosh, Jonatan czy Bankroft zamieniono na sporty odmian Golden Delicious, Gala, Jonagold, Szampion, Idared oraz Ligol. Za owoce tych odmian producenci uzyskują znacznie wyższe ceny na rynku europejskim $\mathrm{i}$ to one gwarantują $\mathrm{w}$ wielu gospodarstwach opłacalną produkcję. Polskie jabłka były wcześniej konkurencyjne cenowo, ale z uwagi na ich niską jakością mogły osiagnąć zdecydowanie niższą cenę w porównaniu do tych z Włoch, Francji czy Holandii. Z chwila, kiedy w owocowanie weszły innego typu sady jabłoniowe Polska zaczęła być postrzegana jako konkurencja i odgrywać coraz większą rolę na światowym rynku tego owocu. Od 2008 roku skala produkcji polskich jabłek ma duży wpływ na poziom ich cen w całej Europie. Jeśli w krajach Unii Europejskiej produkcja jabłek przekracza $11 \mathrm{mln}$ ton, a w Polsce około 2,7 mln ton, wówczas pojawiają się problemy z ich zagospodarowaniem po opłacalnych cenach. Na przykład w Polsce w urodzajnych latach 2008 i 2009 tylko za 25-30\% jabłek uzyskano opłacalne ceny [Makosz 2012a, c, d].

W latach 2000-2010 wzrosła zarówno wartość, jak i wolumen eksportu jabłek - odpowiednio o $173 \%$ - do $6223,9 \mathrm{mln}$ USD oraz o $46 \%$ do $7,7 \mathrm{mln}$ ton. Po stronie eksportu około $43-47 \%$ jabłek pochodzi z Europy, w tym ponad 3,34 mln ton z UE-27, podczas gdy Azja dostarcza 21\% jabłek (Chiny ponad $1 \mathrm{mln}$ ton po $2007 \mathrm{roku}$ ), Ameryka Południowa 13\% (głównie Chile, Argentyna), Ameryka Północna 11\% (zwłaszcza USA), po niespełna 4\% Afryka (RPA około 290 tys. ton) oraz Australia i Oceania (głównie Nowa Zelandia - około 307 tys. ton). Trzema głównymi eksporterami jabłek z UE do 2000 roku byli sadownicy z Francji, połowę ich eksportu na rynek dostarczali Włosi, trzecią pozycję zajmowali Holendrzy, kolejna przypadała Belgom (tab. 5). Jednak od 2009 roku pozycję lidera zajęła Polska. Eksport wyniósł wówczas 777 tys. ton owocu, wobec 661 tys. ton Francji i 732 tys. ton Włoch. Od 2000 do 2009 roku eksport jabłek z Polski wzrósł o $268 \%$ - z poziomu zaledwie 211 tys. ton, podczas gdy Francji spadł o 28\%, czyli 236 tys. ton - do 611 tys. ton. Lukę tę wypełnili zatem między innymi sadownicy z Polski. W eksporcie polskich jabłek od lat dominuja wschodni odbiorcy. Trafiają one na rynki przede wszystkim państw ugrupowania Wspólnoty Niepodległych Państw (WNP). W 2010 roku sprzedano tu ponad 600,9 tys. ton polskich jabłek o wartości około $163 \mathrm{mln}$ EUR. Od lat głównym odbiorca jabłek z Polski jest Rosja ${ }^{2}$, która w 2010 roku zakupiła ponad 337 tys. ton jabłek. Równie dużym zainteresowaniem cieszą się polskie jabłka na rynku białoruskim, litewskim, ukraińskim czy kazachstańskim (w 2010 roku trafiło tam 29,3 tys. ton owoców). Pomimo zmniejszenia ilościowego dostaw jabłek z Polski do krajów UE, trafiło tam w 2010 roku 122, 6 tys. ton o wartości blisko 40 mln EUR. Najwięcej polskich jabłek zaimportowała Rumunia (21 tys. ton),

\footnotetext{
${ }^{2}$ W 2014 roku wprowadziła na produkty rolno-spożywcze, w tym jabłka embargo.
} 
168

Tabela 5

Eksport jabłek w krajach UE-27 w latach 2000-2009 [tys. ton]

\begin{tabular}{|c|c|c|c|c|c|c|c|c|c|c|}
\hline \multirow{2}{*}{ Kraj } & \multicolumn{10}{|c|}{ Lata } \\
\hline & 2000 & 2001 & 2002 & 2003 & 2004 & 2005 & 2006 & 2007 & 2008 & 2009 \\
\hline Polska & 211,6 & 245,9 & 327,8 & 348,7 & 407,4 & 427,0 & 384,8 & 434,5 & 371,0 & 777,1 \\
\hline Włochy & 579,1 & 533,0 & 687,8 & 707,7 & 542,0 & 723,9 & 713,2 & 784,9 & 683,4 & 732,8 \\
\hline Francja & 847,8 & 777,8 & 767,0 & 803,8 & 628,0 & 654,1 & 683,4 & 685,3 & 684,1 & 611,3 \\
\hline Holandia & 286,1 & 234,1 & 258,5 & 349,4 & 388,1 & 444,4 & 355,0 & 395,2 & 391,8 & 406,7 \\
\hline Belgia & 363,4 & 325,4 & 394,8 & 340,1 & 336,7 & 352,8 & 291,3 & 344,3 & 261,9 & 286,3 \\
\hline Hiszpania & 68,3 & 86,7 & 106,5 & 72,7 & 109,3 & 102,0 & 145,8 & 99,3 & 126,1 & 99,4 \\
\hline Niemcy & 67,6 & 73,9 & 64,7 & 69,6 & 89,6 & 93,6 & 99,9 & 146,6 & 111,4 & 96,2 \\
\hline Austria & 43,0 & 44,4 & 43,9 & 70,8 & 50,0 & 71,2 & 88,4 & 86,1 & 78,4 & 85,6 \\
\hline Litwa & 6,2 & 10,3 & 2,2 & 9,4 & 0,7 & 14,1 & 6,7 & 31,2 & 190,2 & 78,0 \\
\hline Czechy & 129,4 & 41,2 & 80,6 & 42,1 & 74,5 & 40,6 & 75,1 & 51,0 & 53,3 & 46,1 \\
\hline Słowenia & 5,1 & 20,6 & 12,8 & 21,1 & 13,2 & 25,8 & 22,0 & 38,9 & 33,1 & 26,1 \\
\hline Węgry & 7,4 & 24,5 & 9,0 & 7,7 & 12,7 & 38,5 & 47,3 & 17,5 & 24,2 & 24,1 \\
\hline W. Brytania & 17,5 & 16,9 & 14,9 & 18,5 & 19,5 & 27,1 & 44,4 & 43,9 & 23,7 & 18,5 \\
\hline Grecja & 24,6 & 66,1 & 18,3 & 30,7 & 30,7 & 47,1 & 37,8 & 32,1 & 23,9 & 17,6 \\
\hline Słowacja & 2,5 & 7,0 & 6,9 & 7,7 & 9,2 & 8,6 & 15,4 & 19,6 & 16,6 & 11,2 \\
\hline Portugalia & 7,5 & 5,7 & 14,8 & 10,3 & 10,5 & 8,4 & 9,2 & 8,6 & 9,9 & 10,7 \\
\hline Irlandia & 1,5 & 1,8 & 1,8 & 1,3 & 1,0 & 2,0 & 4,3 & 7,1 & 6,8 & 7,1 \\
\hline Rumunia & 0,1 & 0,2 & 0,4 & 0,4 & 0,2 & 0,4 & 0,6 & 19,2 & 1,6 & 4,8 \\
\hline Łotwa & 0,1 & 0,0 & 0,0 & 0,0 & 0,2 & 0,5 & 10,8 & 6,2 & 5,3 & 4,0 \\
\hline Dania & 2,1 & 2,6 & 3,8 & 6,8 & 3,7 & 5,1 & 5,0 & 6,5 & 4,2 & 3,7 \\
\hline Bułgaria & 0,1 & 0,2 & 0,1 & 0,1 & 0,0 & 0,0 & 0,1 & 1,3 & 2,4 & 0,3 \\
\hline Szwecja & 5,1 & 1,3 & 0,9 & 1,4 & 2,4 & 1,7 & 2,3 & 1,7 & 0,9 & 0,3 \\
\hline Estonia & 0,1 & 0,1 & 0,0 & 0,0 & 0,1 & 0,1 & 1,4 & 0,2 & 0,1 & 0,2 \\
\hline Luksemburg & 0,6 & 0,7 & 0,4 & 0,5 & 0,1 & 0,1 & 0,2 & 0,2 & 0,2 & 0,2 \\
\hline Malta & 0,0 & 0,1 & 0,0 & 0,0 & 0,0 & 0,0 & 0,0 & 0,0 & 0,1 & 0,1 \\
\hline Finlandia & 0,1 & 0,1 & 0,1 & 0,0 & 0,1 & 0,1 & 0,1 & 0,1 & 0,1 & 0,0 \\
\hline Cypr & 0,1 & 0,0 & 0,0 & 0,0 & 0,0 & 0,0 & 0,0 & 0,0 & 0,0 & 0,0 \\
\hline UE-27 & 2677 & 2520 & 2818 & 2921 & 2723 & 3089 & 3044 & 3261 & 3104 & 3348 \\
\hline Świat & 5277 & 5326 & 5668 & 6236 & 6422 & 7015 & 6999 & 7579 & 7454 & 7757 \\
\hline
\end{tabular}

Źródło: Obliczenia na podstawie Faostat 2012.

Litwa (18,2 tys. ton), Czechy (17,3 tys. ton) i Słowacja (11,2 tys. ton). Ważnym dla sadowników kierunkiem eksportu jabłek jest od lat rynek niemiecki, estoński, szwedzki i łotewski.

Do krajów UE w ramach rynku wewnętrznego do 2010 roku trafiało około 2,7-3,1 mln ton jabłek. Spoza obszaru wspólnoty jabłka w celu uzupełnienia kra- 
jowego asortymentu importowano z Ameryki Północnej (USA, Kanady), Ameryki Południowej (Argentyny, Chile), Afryki - głównie z RPA, a nawet z Australii oraz Nowej Zelandii. Do Polski jabłka sprowadzane są przede wszystkim z terytorium UE, głównie z Holandii, Włoch, Belgii, i Czech. Ale na polskich stołach goszczą także jabłka z Chile, Argentyny oraz RPA.

Dobrze rozwinięta baza przechowalnicza sprawia, że zmniejsza się wyraźnie sezonowość dostaw owoców, a te, które docierają z zagranicy, stanowią jedynie urozmaicenie oferty asortymentowej na półkach sklepowych. Ich import, w zależności od kraju, to od kilku do kilku tysięcy ton rocznie, a zatem stanowią niewielką skalę w stosunku do odmian krajowych.

Większa podaż krajowa jabłek wpływa na spadek ich importu, jednak ich skala zależy także od popytu na rynku wewnętrznym. Ponadto w strukturze konsumpcji zwiększa się substytucja krajowych owoców owocami pochodzącymi z importu - zwłaszcza południowych i ze strefy umiarkowanej. Jabłka w okresach jesienno-zimowych stopniowo zastępowane są bananami, pomarańczami, grejpfrutami, brzoskwiniami czy winogronami.

Warto w tym miejscu wspomnieć, że polskie jabłka - odmiany przemysłowe - są, ze względu na kwasowość, poszukiwanym surowcem do produkcji koncentratu soku jabłkowego. W UE poza Polską głównymi jego producentami są Niemcy, Węgry, Hiszpania, Rumunia i Austria, łącznie wytwarzając 97\%. Skala eksportu w 2010 roku wynosiła 239 tys. ton za kwotę $181 \mathrm{mln}$ EUR, stanowiąc około 3/4 udziału w eksporcie soków.

Światowy import jabłek w 2000 roku wynosił 4,88 mln ton, podczas gdy pod koniec dekady ponad 7,4 mln ton. Jego wartość wyrażona w cenach bieżących wzrasta o 164\% - do ponad 6,6 mld USD. Głównymi kierunkami zakupu jabłek są Europa, a przede wszystkim kraje UE-27 (pomimo spadku udziału ich w strukturze globalnego importu z 55,4 do 37,4\%) oraz Rosja. Pokaźny import jabłek trafia do Meksyku (około 195 tys. ton), USA (około 170 tys. ton), Chin (165 tys. ton), a także Kanady (150 tys. ton). Ważnymi parterami handlowymi są także Arabia Saudyjskiej i Indonezja (powyżej 110 tys. ton). W UE-27 dominująca część importowanych jabłek sprowadzana jest do Niemiec (około 20-28\%), Wielkiej Brytanii (16-18\%), Holandii (8-13\%) oraz Hiszpanii i Belgii (w granicach 6-9\%) - tabela 6. Zwłaszcza Belgia oraz Holandia wyspecjalizowały się w reeksporcie jabłek na obszarze UE, a po 2008 roku dołączyła do nich także Litwa. W Polsce import jabłek był niewspółmiernie wysoki do dotychczas notowanego w 2008 roku, kiedy osiagnał poziom 138 tys. ton. W 2010 roku w kraju były niekorzystne zbiory jabłek - 1859 tys. ton wobec 2626 tys. ton w 2009 roku, czy 2831 tys. ton w 2008 roku. W eksporcie w 2010 roku odnotowano niewielkie zmniejszenie wolumenu jabłek, które cechowały się gorszą niż w poprzednich latach jakością. Za granice trafiło wówczas 728,5 tys. ton o łącznej wartości 205,1 mln EUR. 
Tabela 6

Import jabłek do krajów UE w latach 2000-2009 [tys. t]

\begin{tabular}{|c|c|c|c|c|c|c|c|c|c|c|}
\hline \multirow{2}{*}{ Kraj } & \multicolumn{10}{|c|}{ Lata } \\
\hline & 2000 & 2001 & 2002 & 2003 & 2004 & 2005 & 2006 & 2007 & 2008 & 2009 \\
\hline Niemcy & 683 & 652 & 777 & 813 & 736 & 774 & 699 & 669 & 613 & 623 \\
\hline W. Brytania & 426 & 466 & 449 & 476 & 525 & 514 & 532 & 523 & 482 & 456 \\
\hline Holandia & 225 & 260 & 280 & 387 & 323 & 320 & 365 & 400 & 396 & 360 \\
\hline Hiszpania & 225 & 178 & 208 & 236 & 249 & 225 & 189 & 238 & 228 & 239 \\
\hline Belgia & 227 & 224 & 247 & 250 & 222 & 226 & 214 & 225 & 178 & 172 \\
\hline Francja & 84 & 117 & 138 & 116 & 210 & 185 & 152 & 178 & 148 & 161 \\
\hline Szwecja & 85 & 79 & 79 & 93 & 104 & 112 & 108 & 104 & 92 & 83 \\
\hline Litwa & 33 & 27 & 28 & 32 & 32 & 34 & 128 & 172 & 175 & 80 \\
\hline Dania & 63 & 65 & 69 & 75 & 67 & 65 & 68 & 69 & 70 & 77 \\
\hline Portugalia & 66 & 78 & 64 & 63 & 72 & 74 & 69 & 86 & 70 & 63 \\
\hline Czechy & 47 & 38 & 38 & 44 & 45 & 70 & 79 & 70 & 69 & 61 \\
\hline Austria & 224 & 102 & 62 & 80 & 81 & 102 & 87 & 116 & 116 & 60 \\
\hline Irlandia & 39 & 42 & 45 & 49 & 49 & 46 & 60 & 67 & 61 & 59 \\
\hline Finlandia & 54 & 55 & 46 & 53 & 54 & 49 & 49 & 55 & 51 & 49 \\
\hline Słowacja & 32 & 24 & 30 & 33 & 29 & 32 & 33 & 46 & 40 & 37 \\
\hline Włochy & 31 & 36 & 54 & 56 & 90 & 53 & 38 & 43 & 61 & 37 \\
\hline Rumunia & 21 & 14 & 23 & 45 & 41 & 86 & 90 & 54 & 39 & 32 \\
\hline Polska & 15 & 22 & 5 & 13 & 7 & 25 & 22 & 138 & 39 & 22 \\
\hline Grecja & 12 & 21 & 27 & 26 & 26 & 22 & 22 & 20 & 18 & 21 \\
\hline Bułgaria & 22 & 33 & 35 & 32 & 27 & 36 & 43 & 37 & 33 & 18 \\
\hline Słowenia & 32 & 4 & 9 & 3 & 6 & 7 & 9 & 7 & 17 & 18 \\
\hline Łotwa & 25 & 26 & 19 & 21 & 22 & 17 & 13 & 13 & 14 & 16 \\
\hline Estonia & 14 & 13 & 13 & 17 & 18 & 12 & 11 & 13 & 13 & 14 \\
\hline Węgry & 6 & 4 & 9 & 9 & 4 & 11 & 0 & 71 & 21 & 9 \\
\hline Cypr & 3 & 3 & 3 & 2 & 2 & 4 & 6 & 6 & 6 & 8 \\
\hline Malta & 8 & 8 & 7 & 7 & 6 & 5 & 5 & 5 & 5 & 5 \\
\hline Luksemburg & 5 & 5 & 6 & 6 & 5 & 5 & 6 & 6 & 6 & 5 \\
\hline UE-27 & 2706 & 2595 & 2769 & 3036 & 3052 & 3110 & 3095 & 3422 & 3062 & 2787 \\
\hline Świat & 4881 & 5009 & 5392 & 5984 & 6243 & 6572 & 6940 & 7401 & 7354 & 7396 \\
\hline
\end{tabular}

Źródło: Obliczenia na podstawie danych Faostat 2012.

Z prognoz FAO wynika, że produkcja jabłek na świecie do 2015 roku ma wzrosnąć do około $80 \mathrm{mln}$ ton, a eksport do blisko $10 \mathrm{mln}$ ton. Spodziewać należy się, że zwiększy się eksport do krajów dotychczas mniej docenianych, aczkolwiek dynamicznie rozwijających się - Bliskiego Wschodu i Afryki, gdzie jabłka nie były uznawane za produkt podstawowy w codziennej konsumpcji, 
lecz luksusowy. Nadal największym importerem jabłek będzie Rosja, a poza nią Niemcy i Wielka Brytania. Na globalnym rynku trzeba będzie się liczyć z coraz większą konkurencją, zwłaszcza po stronie produkcyjno-podażowej. Niebagatelną rolę odegrają $\mathrm{w}$ tej grze rynkowej ceny owoców, ich jakość, a ponadto koszty transportu oraz kurs walutowy. Najwyższe ceny za tonę jabłek uzyskują producenci w Japonii (około 2 tys. USD), w granicach $0,8-1,4$ tys. USD za tonę w Finlandii czy Luksemburgu (421-1758 USD) - tabela 7. Ceny na rynku owoców są zmienne, a zakłócenia wynikają m.in. ze specyfiki produktów. Są to towary nietrwałe, a ich podaż w dużej mierze zależy od warunków pogodowych [Domagalska-Grędys 2006].

Za wysokie ceny należy uznać także te w Wielkiej Brytanii oraz na Cyprze. W większości krajów UE w latach 2000-2009 za tonę jabłek trzeba było zapłacić przeciętnie około 500 USD. Od wielu lat w Polsce są najniższe ceny jabłek zarówno w skupie, jak i w sprzedaży detalicznej. Ponadto sadownicy mogą zaoferować na jesieni zagranicznym odbiorcom jabłka wysokiej jakości w cenie około 0,3 euro za kg, jednak o ich poziomie decyduje plon uzyskany z hektara, koszty produkcji oraz zbiór w danym roku, a także aktualny kurs waluty.

Poziom cen skupu jabłek deserowych i przemysłowych ma odzwierciedlenie w poziomie opłacalności produkcji sadowniczej również w Polsce. Na krajowym rynku funkcjonuje konkurencja nie tylko pomiędzy zakładami przetwórczymi o jakość skupowanego surowca, ale także o parametry jakościowe owoców z firmami eksportującymi. Obecnie producenci jabłek dysponują bardzo dużymi powierzchniami przechowalniczymi i z tego tytułu mogą podejmować dogodne dla nich decyzje odnośnie sprzedaży produktu nie tylko w sezonie. Zagospodarowanie jabłek odbywa się zatem systematycznie i jest rozłożone w czasie, a jakość owoców jest wysoka nawet w I półroczu kolejnego roku. Ta rozbudowana i nowoczesna forma długotrwałego magazynowania produktów sprzyja niwelowaniu wahań na rynku surowca. Możliwość jej rozbudowy poprzez zwiększenie mocy przechowalniczych, jak podkreślają specjaliści IERiGŻ-PIB, miała miejsce, ponieważ wykorzystywano do tego unijne fundusze. Co więcej, producenci jabłek integrują się i tworzą duże grupy oraz organizacje sadowników, zwiększając tym samym swoją siłę przetargową poprzez nie tylko większą zdolność szybkiego przygotowania dużych i zestandaryzowanych partii jabłek wysokiej jakości (klasy extra, I), ale dostarczenia ich w możliwie krótkim czasie do najdalszych zakątków (nie tylko Europy), np. Kazachstanu, Azerbejdżanu, Armenii, Iraku, Mongolii, gdzie dociera coraz mniej jabłek z Chin.

Porównując poziom spożycia jabłek przez statystycznego mieszkańca w krajach UE-27 (tab. 8) wynika, że najwyższy występuje w Holandii i Danii - ponad 
Tabela 7

Ceny za tonę jabłek uzyskiwane przez producenta w wybranych krajach UE w latach 2000-2009 [USD/t]

\begin{tabular}{|c|c|c|c|c|c|c|c|c|c|c|}
\hline \multirow{2}{*}{ Kraj } & \multicolumn{10}{|c|}{ Lata } \\
\hline & 2000 & 2001 & 2002 & 2003 & 2004 & 2005 & 2006 & 2007 & 2008 & 2009 \\
\hline Finlandia & 829 & 1023 & 945 & 1608 & 1824 & 1088 & 1487 & 2090 & 1876 & 1667 \\
\hline Luksemburg & 421 & 530 & 772 & 1185 & 1243 & 1246 & 1256 & 1439 & 1758 & 1625 \\
\hline Cypr & 819 & 827 & 999 & 1063 & 1068 & 928 & 953 & 860 & 1013 & 1040 \\
\hline W. Brytania & 619 & 602 & 679 & 900 & 964 & 859 & 942 & 1159 & 1109 & 981 \\
\hline Grecja & 330 & 401 & 514 & 670 & 731 & 637 & 660 & 795 & 970 & 954 \\
\hline Portugalia & 503 & 492 & 468 & 562 & 725 & 761 & 660 & 799 & 960 & 801 \\
\hline Niemcy & 302 & 325 & 388 & 551 & 562 & 442 & 544 & 626 & 793 & 799 \\
\hline Dania & 436 & 470 & 546 & 770 & 869 & 600 & 736 & 876 & 814 & 740 \\
\hline Rumunia & 420 & 317 & 370 & 387 & 428 & 608 & 713 & 916 & 1040 & 730 \\
\hline Szwecja & 386 & 400 & 461 & 526 & 541 & 611 & 637 & 721 & 871 & 721 \\
\hline Słowenia & 271 & 288 & 305 & 423 & 377 & 384 & 397 & 574 & 868 & 604 \\
\hline Francja & 257 & 315 & 311 & 402 & 488 & 426 & 585 & 666 & 704 & 573 \\
\hline Bułgaria & 63 & 60 & 85 & 55 & 45 & 64 & 75 & 465 & 795 & 505 \\
\hline Austria & 236 & 291 & 323 & 479 & 436 & 373 & 389 & 544 & 732 & 500 \\
\hline Holandia & 251 & 313 & 197 & 301 & 333 & 374 & 527 & 576 & 762 & 500 \\
\hline Malta & 333 & 304 & 415 & 559 & 433 & 441 & 390 & 487 & 511 & 499 \\
\hline Belgia & 226 & 313 & 273 & 507 & 499 & 435 & 568 & 588 & 802 & 493 \\
\hline Słowacja & 232 & 249 & 268 & 321 & 345 & 342 & 343 & 449 & 525 & 471 \\
\hline Estonia & 116 & 118 & 167 & 249 & 346 & 297 & 390 & 385 & 469 & 427 \\
\hline Hiszpania & 235 & 262 & 341 & 445 & 459 & 356 & 415 & 579 & 574 & 415 \\
\hline Czechy & 182 & 223 & 249 & 292 & 327 & 326 & 381 & 319 & 235 & 382 \\
\hline Litwa & 59 & 23 & 34 & 281 & 290 & 213 & 131 & 540 & 580 & 354 \\
\hline Łotwa & 71 & 56 & 70 & 91 & 267 & 115 & 225 & 306 & 418 & 304 \\
\hline Polska & 59 & 49 & 57 & 110 & 90 & 160 & 155 & 362 & 169 & 103 \\
\hline Węgry & 65 & 49 & 45 & 83 & 60 & 126 & 131 & 308 & 101 & 64 \\
\hline Włochy & 294 & 362 & 340 & 419 & 483 & 384 & 367 & 446 & $\mathrm{bd}$ & $\mathrm{bd}$ \\
\hline
\end{tabular}

Źródło: Obliczenia na podstawie danych Faostat 2012.

50 kg w skali roku, a najniższy 5-8 kg/osobę w Rumunii, na Litwie czy w Wielkiej Brytanii. Polska, mimo że jest głównym producentem i eksporterem jabłek, plasuje się w połowie listy, z konsumpcją około 16,9 kg w 2010 roku. W kraju od lat notuje się spożycie owoców rzędu około $45 \mathrm{~kg}$ na osobę, w tym jabłek około 1/3 jabłek, przy blisko 1/4 owoców cytrusowych (10-12 kg/osób). Na korzyść jabłek przemawia fakt, że były one relatywnie tańsze od popularnych owoców południowych. W latach 2004-2010 wzrasta siła nabywcza przeciętnego dochodu rozporządzalnego przypadającego na 1 osobę w gospodarstwie domowym 
Tabela 8

Konsumpcja jabłek w wybranych krajach UE w latach 2000-2010 [kg/osobę]

\begin{tabular}{|l|c|c|c|c|c|c|c|c|c|c|c|}
\hline \multirow{2}{*}{ Kraj } & \multicolumn{10}{|c|}{ Lata } \\
\cline { 2 - 14 } & 2000 & 2001 & 2002 & 2003 & 2004 & 2005 & 2006 & 2007 & 2008 & 2009 & 2010 \\
\hline Holandia & bd & bd & bd & bd & bd & bd & bd & 31,2 & 10,5 & 46,0 & 54,4 \\
\hline Dania & 21,6 & 29,9 & 46,3 & 26,8 & 67,0 & 51,2 & 49,2 & 53,5 & bd & bd & bd \\
\hline Austria & 23,5 & 27,1 & 28,6 & 24,9 & 23,4 & 24,8 & 22,4 & 21,3 & 22,4 & 21,7 & 19,5 \\
\hline Portugalia & 28,0 & 28,1 & 28,3 & 30,6 & 30,2 & 30,0 & bd & 27,1 & 26,9 & 26,5 & 26,4 \\
\hline Włochy & 29,3 & 22,6 & 27,1 & 31,1 & 14,6 & 25,2 & 19,0 & 17,5 & 16,6 & 19,9 & 22,5 \\
\hline Francja & 18,3 & 21,1 & 21,4 & 22,1 & 20,5 & 23,2 & 21,8 & 21,9 & 21,4 & 20,7 & 21,4 \\
\hline Luksemburg & 42,4 & 45,4 & 22,8 & 33,2 & 22,5 & 25,5 & 21,8 & 21,3 & 23,5 & 20,7 & 21,8 \\
\hline Belgia & 27,3 & 27,7 & 21,9 & 21,2 & 23,2 & 23,3 & 24,5 & 26,0 & bd & bd & bd \\
\hline Grecja & 22,9 & 23,0 & 16,3 & 21,6 & 19,5 & 23,4 & 20,6 & 26,7 & bd & bd & bd \\
\hline Estonia & 25,6 & 26,0 & 26,2 & 24,3 & 24,7 & 19,7 & 25,1 & 25,2 & 23,6 & 16,4 & 19,5 \\
\hline Niemcy & 19,9 & 18,4 & 16,6 & 16,9 & 17,4 & 16,7 & 18,0 & 17,0 & 17,3 & 17,0 & 18,3 \\
\hline Szwecja & 19,7 & 18,4 & 14,9 & 19,8 & 23,1 & 15,0 & 21,8 & 21,9 & 20,4 & 17,4 & 17,3 \\
\hline Polska & bd & bd & 37,3 & 30,1 & 13,2 & 11,6 & 7,9 & 0,8 & 3,8 & 11,3 & 16,9 \\
\hline Irlandia & 12,4 & 18,3 & 17,7 & 12,6 & 12,6 & 12,4 & 12,8 & 21,4 & 13,9 & 13,8 & 13,8 \\
\hline Węgry & bd & 17,1 & 12,1 & 13,6 & 20,4 & 24,9 & 20,9 & 24,5 & 10,1 & 21,2 & 13,2 \\
\hline Malta & 8,4 & 20,7 & 19,5 & 17,4 & 17,5 & 7,2 & 20,7 & 16,0 & 12,9 & 17,0 & 13,6 \\
\hline Hiszpania & 20,4 & 20,4 & 20,0 & 15,9 & 16,9 & 16,8 & 13,7 & 19,3 & bd & bd & bd \\
\hline Litwa & bd & bd & bd & 19,5 & 13,4 & 10,1 & 7,3 & 6,1 & 2,4 & 8,8 & 4,3 \\
\hline Rumunia & bd & bd & 11,5 & bd & bd & 17,9 & 15,0 & 13,3 & 23,6 & 5,0 & 6,5 \\
\hline Słowacja & bd & bd & bd & bd & bd & bd & bd & bd & 11,9 & 12,8 & 15,7 \\
\hline Finlandia & bd & bd & bd & & 22,3 & 22,0 & bd & bd & bd & bd & bd \\
\hline W. Brytania & 13,0 & 10,9 & 11,0 & 8,7 & 12,1 & 3,2 & 11,6 & 11,7 & bd & bd & bd \\
\hline
\end{tabular}

Źródło: Eurostat 2012.

w przypadku zakupu jabłek z $335 \mathrm{~kg}$ do $511 \mathrm{~kg}$, a na tę sytuację w 2009 roku wywarły pozytywny wpływ, w przypadku jabłek deserowych, relatywnie niższe ceny (prawie o 30\%), przy rosnących realnie dochodach.

\section{Podsumowanie}

Na podstawie przeprowadzonej analizy zmian, głównie po stronie produkcyjnej jabłek, w krajach obecnie należących do Unii Europejskiej w latach 2000-2010 można wysunąć następujące wnioski:

1. Zmniejszyła się o $25 \%$ powierzchnia upraw jabłoni - do ok. 550 tys. ha, zwłaszcza w Niemczech (o 75\%), poza Polską (o 14\%) i Wielką Brytanią (od 2003 roku wzrost o około $20 \%$ ), przy rosnącej produkcji i plonie z hektara. 
2. Największymi producentami jabłek do 2004 roku w UE były Włochy oraz Francja, wraz z rozszerzeniem Wspólnoty na drugą pozycję wysunęła się Polska, stanowiąc z pozostałymi dwoma państwami $55 \%$ produkcji tych owoców.

3. Pomiędzy krajami UE występują duże różnice w zakresie uzyskiwanego plonu jabłek z hektara, co wynika m.in.: ze specjalizacji produkcji, specyfiki obszarowej gospodarstw sadowniczych, ich wyposażenia w nowoczesne maszyny i urządzenia oraz właściwego doboru do stanowiska odmian itd. Najwyższe osiaggają sadownicy w Austrii, są one niemal 1,5-krotnie większe niż w Holandii, Belgii czy we Włoszech. Na 15. pozycji w klasyfikacji jest Polska (osiągając zaledwie 18\% poziomu Austrii).

4. Intensyfikacja produkcji towarowej w sadach sprawia, że w strukturze nasadzeń tracą na znaczeniu odmiany starsze na rzecz najbardziej poszukiwanych i cenionych wśród konsumentów Golden Delicious, Gala czy Red Delicious.

5. Nadal największymi eksporterami jabłek są sadownicy włoscy (533-732 tys. ton), francuscy (spadek o $28 \%$ z 847 tys. ton), holenderscy (wzrost z 234 do 406 tys. ton) i polscy (wzrost 2,6-krotny do 777 tys. ton).

6. Obrót jabłkami głównie odbywa się w ramach rynku wewnętrznego Wspólnoty, Niemcy kupują od 613 do 813 tys. ton jabłek rocznie, Wielka Brytania między 426 a 532 tys. ton, Holandia do 400 tys. ton, a Hiszpania około 210 tys. ton.

7. Ważnymi od lat partnerami handlowymi spoza wspólnoty są kraje WNP, zwłaszcza Rosja, Białoruś i Ukraina.

8. Za pozytywne należy uznać w przypadku Polski to, że rośnie potencjał sadów jabłoniowych o wysokim stopniu intensywności produkcji. Zarówno na rynek krajowy, jak i zagraniczny dostarczane są owoce o coraz wyższych parametrach handlowych, przemysłowych, jak i deserowych. W latach 2004-2010 trwał ich eksport, na nienotowaną dotąd skalę, a o ich atrakcyjności w Europie decydowały konkurencyjna, relatywnie niższa i dająca wciąż opłacalność produkcji cena owocu w sprzedaży.

\section{Literatura}

Aplles Industry \& Trade Summary Office of Industries Publication United States International Trade Commissionits, Washington, DC 20436, 04 February 2010: www.usitc.gov (data dostępu: 13.02.2014).

Baza danych Eurostat 2012: http://epp.eurostat.ec.europa.eu (data dostępu: 20.02.2014). 
Belrose Inc., World Apple Review 2008 Aplles Industry \& Trade Summary Office of Industries Publication United States International Trade Commissionits, Washington, DC 20436, 04 February 2010, www.usitc.gov (data dostępu: 19.02.2014).

BUGAŁA A., 2014: Światowy rynek jabłek $i$ zagęszczonego soku jabłkowego, Zeszyty Naukowe Szkoły Głównej Gospodarstwa Wiejskiego w Warszawie, Problemy Rolnictwa Światowego, tom 14 (XXIX), Zeszyt 2, s. 21-30.

DOMAGALSKA-GRĘDYS M., 2006: Ocena polskich sadów jabłoniowych z uwzględnieniem odmian $w$ poczatkowym okresie czlonkostwa $w$ UE, Zeszyty Naukowe Szkoły Głównej Gospodarstwa Wiejskiego w Warszawie, Problemy Rolnictwa Światowego tom XV, s. 16-25.

HESTER S.M., CACHO O., 2003: Modelling apple orchard systems, Agricultural Systems vol. 77, Issue 2, August, s.137-154.

KAWECKA Z., KRYŃSKA W. (red.), 1992: Sadownictwo i warzywnictwo, PWN, Warszawa, s. 5-12.

MAKOSZ E., 2012a: 40 lat polskiego sadownictwa, www.sadnowoczesny.pl (data dostępu: 15.06.2012).

MAKOSZ E., 2012b: Jabłko - nasz owoc narodowy, www.sadnowoczesny.pl (data dostępu: 25.06.2012).

MAKOSZ E., 2012c: Konkurencyjne polskie jabłka deserowe, www.sadnowoczesny.pl (data dostępu: 15.03.2012).

MAKOSZ E., 2012d: Konkurencyjni na europejskim rynku jabłek, www.sadnowoczesny.pl (data dostępu: 16.02.2012).

MAZURKIEWICZ-PIZŁO A., PIZŁO W., 2011: Stan i kierunki rozwoju sadownictwa w Polsce - lata 1999-2010, [w:] Gospodarowanie w sadownictwie Grójca i Warki: region, klastry, gospodarstwa sadownicze (część pierwsza), red. W. Pizło, Wydawnictwo SGGW, Warszawa.

PIZŁO W., 2014: Perspektywy rozwoju gospodarstw jabłoniowych w Polsce na tle wybranych krajów UE, Zeszyty Naukowe Szkoły Głównej Gospodarstwa Wiejskiego w Warszawie, Problemy Rolnictwa Światowego, Tom 14 (XXIX) 2014, Zeszyt 2, s. 185-193.

PONIEDZIAŁEK W. 2001: Sadownictwo subtropikalne, Państwowe Wydawnictwo Rolnicze i Leśne, Warszawa, s. 5-25.

REJMAN A. (red.),1994: Pomologia odmianoznawstwo roślin sadowniczych, Państwowe Wydawnictwo Rolnicze i Leśne, Warszawa, s. 19.

Rynek owoców i warzyw za lata 2006-2013. Analizy rynkowe, IERiGŻ-BIP, ARR, MRiRW, Warszawa.

Sadownictwo i szkótkarstwo, Podręcznik dla techników ogrodniczych i policealnych studiów zawodowych. Wyd. II. PWRiL, Warszawa 1995, s. 181. 


\title{
Changes on the apple market in the European Union countries between 2000-2010
}

\begin{abstract}
The article presents information concerning changes undergoing on the EU market of fresh apples between 2000-2010. The author shows changes in production, consumption, foreign trade and prices, of the main stakeholders (producers, consumers, exporters and importers), including Poland. Secondary sources of information were used for the analysis, originating from Faostat 2012 and GUS data bases. The analysis was carried out under a research project (grant agreement No 3745/B/H03/2011/40), which was funded by National Science Centre. The analysis involved comparative as well as descriptive methods.
\end{abstract}

